\title{
Distribution, abundance and biomass of Chaetognaths off São Sebastião region, Brazil in February 1994
}

\author{
Tsui-Hua Liangl \& Luz Amelia Vega-Pérez ${ }^{2}$ \\ 1 Universidade Federal do Pará \\ Campus Universitário de Bragança, \\ (Alameda Leandro Ribeiro s/n, 68600-000 Bragança, PA, Brasil) \\ tsuihua@hotmail.com \\ 2Instituto Oceanográfico da Universidade de São Paulo \\ (Praça do Oceanográfico, 191 Butantã 05508-900 São Paulo, SP, Brasil) \\ lavega@usp.br
}

- Abstract: The distribution, abundance, biomass, population structure and feeding habits of chaetognaths collected off São Sebastião region, Brazil, in February 1994 are described. Bongo nets were hauled obliquely to collect zooplankton samples. Forty-three samples obtained with the $333 \mu \mathrm{m}$ mesh were analysed. In this study, 7 chaetognath species belonging to two genera were identified. Sagitta friderici, S. temis and S. bipunctata were grouped into the neritic category, and Sagitta enflata, S. hispida, S. minima and Krohnita pacifica into the semi-neritic group. The analysis of the community structure distinguished 3 zones: 1) a nearshore zone evidenced by low richness; 2) an offshore zone evidenced by higher number of species and 3) another offshore zone, located south and south-westward of São Sebastião Island, characterised by higher richness but with dominance of one species. The nearshore zone was dominated by the neritic species $S$. friderici and $S$. temuis, whereas the offshore zone was dominated by $S$. enflata. Abundance and biomass increase from nearshore toward offshore zones by about two orders of magnitude. Gut content analysis revealed over $90 \%$ of empty guts. The chaetognath population was composed mainly of juveniles. The diets among the different chaetognath species was very similar, composed mostly of small copepods and appendicularians.

- Resumo: No presente trabalho foram estudados a distribuição, abundância, biomassa, estrutura da população e hábito alimentar dos quetógnatos coletados na região de São Sebastião, Brasil, em fevereiro de 1994. As 43 amostras de zooplâncton utilizadas na elaboração deste trabalho foram obtidas através de arrastos oblíquos usando uma rede Bongô $(333 \mu \mathrm{m})$, providas de fluxômetro. Foram identificadas sete espécies de Chaetognatha pertencentes a dois gêneros. Sagitta friderici, S. tenuis e $S$. bipunctata foram agrupadas como espécies neríticas, enquanto que Sagitta enflata, S. hispida, S. minima e Krohnita pacifica semi-neriticas. A análise da estrutura da comunidade, mostrou a existência de 3 zonas: 1) zona costeira caracterizada por poucas espécies; 2) zona oceânica com muitas espécies e 3) zona oceânica, ao sul e sudoeste da Ilha de São Sebastião, com muitas espécies, mas predominância de uma espécie. A zona nerítica foi dominada pelas espécies $S$. friderici e $S$. temuis, e a zona oceânica por S.enflata. Abundância e biomassa do grupo aumentou da região costeira para a oceânica. A população foi composta principalmente de jovens. A análise do conteúdo intestinal revelou mais de $90 \%$ de indivíduos com o trato digestivo vazio. A dieta das diferentes espécies foi bastante similar, sendo composta principalmente de pequenos copépodos e apendiculários.

- Descriptors: Chaetognatha, Distribution, Abundance, Biomass, Feeding habits, Brazil.

- Descritores: Chaetognatha, Distribuição, Abundância, Biomassa, Hábito alimentar, Brasil. 
Rev. bras. oceanogr., 50(único), 2002

\section{Introduction}

Like most coastal environments, the São Sebastião region suffers from the effects of human activities such as domestic waste water discharges and intense tourism. Moreover, this region is frequently under effects of oil spills (Lamparelli \& Moura, 1999). A multidisciplinary project was designed to investigate the structure and functioning of the coastal ecosystem off São Sebastião region. As part of this project, the present paper focused on chaetognaths, a small and evolutionary isolated group of animals (Hyman, 1959), ubiquitous in the marine plankton.

The phylum Chaetognatha comprises about one hundred species of small size, between 2 and 120 $\mathrm{mm}$ in length, living in various marine habitats (Casanova, 1999). They are ubiquitous and extremely abundant in the marine plankton, often surpassed by copepods in number (Feigenbaum \& Maris, 1984). The distribution and abundance of these organisms are related with local hydrological conditions (Heydorn, 1959) and their food (Alvariño, 1969). Some species are closely associated with specific water masses (Grant, 1991; Liang \& Vega-Pérez, 2001), being considered as excellent indicators of water masses movements (Cheney, 1985).

Chaetognaths are considered to play a central role in the pelagic food webs, serving as the main link between copepods and higher trophic levels (Alvariño, 1985). Chaetognaths are one of the most active predators among zooplankters, and they can remove a substantial fraction of prey production each day (Kimmerer, 1984). The dominance of chaetognaths over other pelagic predators (Oresland, 1987) in number and their presence throughout the year in the zooplankton samples, indicate the prominence of this group.

This study aims to describe the abundance, distribution, biomass, population structure and feeding habits of chaetognaths collected off São Sebastião region, Brazil, in February 1994.

\section{Study area}

The study area, the São Sebastião region $\left(23^{\circ} 30^{\prime} \mathrm{S}-24^{\circ} 15^{\prime} \mathrm{S} ; 45^{\circ} 00^{\prime} \mathrm{W}-45^{\circ} 45^{\prime} \mathrm{W}\right)$ lies on the northern coast of the São Paulo State, Brazil, and is characterised by a broad continental shelf extending over approximately $100 \mathrm{~km}$ in length. The coastline has many peninsulas, bays and inlets that, with São Sebastião island as well as other islets, act altogether to attenuate the energy of waves originating at the open sea and hence to lower the hydrodynamism.

In February 1994, two types of water masses were described in the region (Castro Filho \&
Miranda, 1997): one is the Coastal Water (CW), with oligotrophic features, temperatures higher than $20^{\circ} \mathrm{C}$ and salinity lower than $35 \mathrm{psu}$. It was found in the surface layer above $25 \mathrm{~m}$ depth. The other water mass is the South Atlantic Central Water (SACW), rich in nutrients and characterised by lower temperatures $\left(<18^{\circ} \mathrm{C}\right)$ and salinity ranging from 35 to $36 \mathrm{psu}$. The SACW flows in the deeper layers, below $30 \mathrm{~m}$ depth.

\section{Material and methods}

Zooplankton samplings were conducted aboard the R/V Prof. W. Besnard in the São Sebastião region from February $7^{\text {th }}$ to $10^{\text {th }}, 1994$ over a grid of 43 oceanographic stations (Fig. 1). A total of 86 zooplankton samples were collected with Bongo nets fitted with $333 \mu \mathrm{m}$ and $505 \mu \mathrm{m}$ mesh size, provided with digital flowmeters for measurement of filtered water volume. For this study, 43 samples obtained using the $333 \mu \mathrm{m}$ mesh size net were analysed. Double oblique hauls were made from the surface to $5 \mathrm{~m}$ above the bottom of the sea and to surface, during 5-10 minutes, maintaining the velocity of vessel of about 1.5 knots. The collected samples were immediately fixed on board with a solution of $4 \%$ formaldehyde in seawater buffered with borax. Hydrographical data were obtained by means of Nansen bottles at standard depths $(0,5,10,20,30,40$ and $50 \mathrm{~m}$ ).

All chaetognaths were removed from the total sample or at least 1000 specimens were sorted out from aliquots subsampled using a Motoda splitter. Chaetognaths were identified to species level (Alvariño, 1969; McLelland, 1989; Casanova, 1999) under stereomicroscope. Chaetognath specimens were examined for stage of maturity using Reeve's (1970) classification: stage 0 - no gonads; stage I gonads being formed; stage II - ova small and all alike in size; stage III - some ova enlarged to mature size, seminal vesicles matured; stage IV - all ova enlarged. The number of chaetognaths was expressed as individuals per square meter (Tanaka, 1973).

The total length (excluding caudal fin) was measured using an ocular micrometer. About 10 20 individuals of each size class of each species were placed in an aluminium foil of known weight in order to determine the wet weight and dry weight. The biomass of each species, expressed as $\mathrm{mg}$ wet weight per square meter ( $\mathrm{mg} \mathrm{WW}^{-2}$ ) and $\mathrm{mg}$ dry weight per square meter ( $\mathrm{mg}$ DW $\mathrm{m}^{-2}$ ), was determined by sum of the product of individual mean weight of each maturity stage and the abundance. 


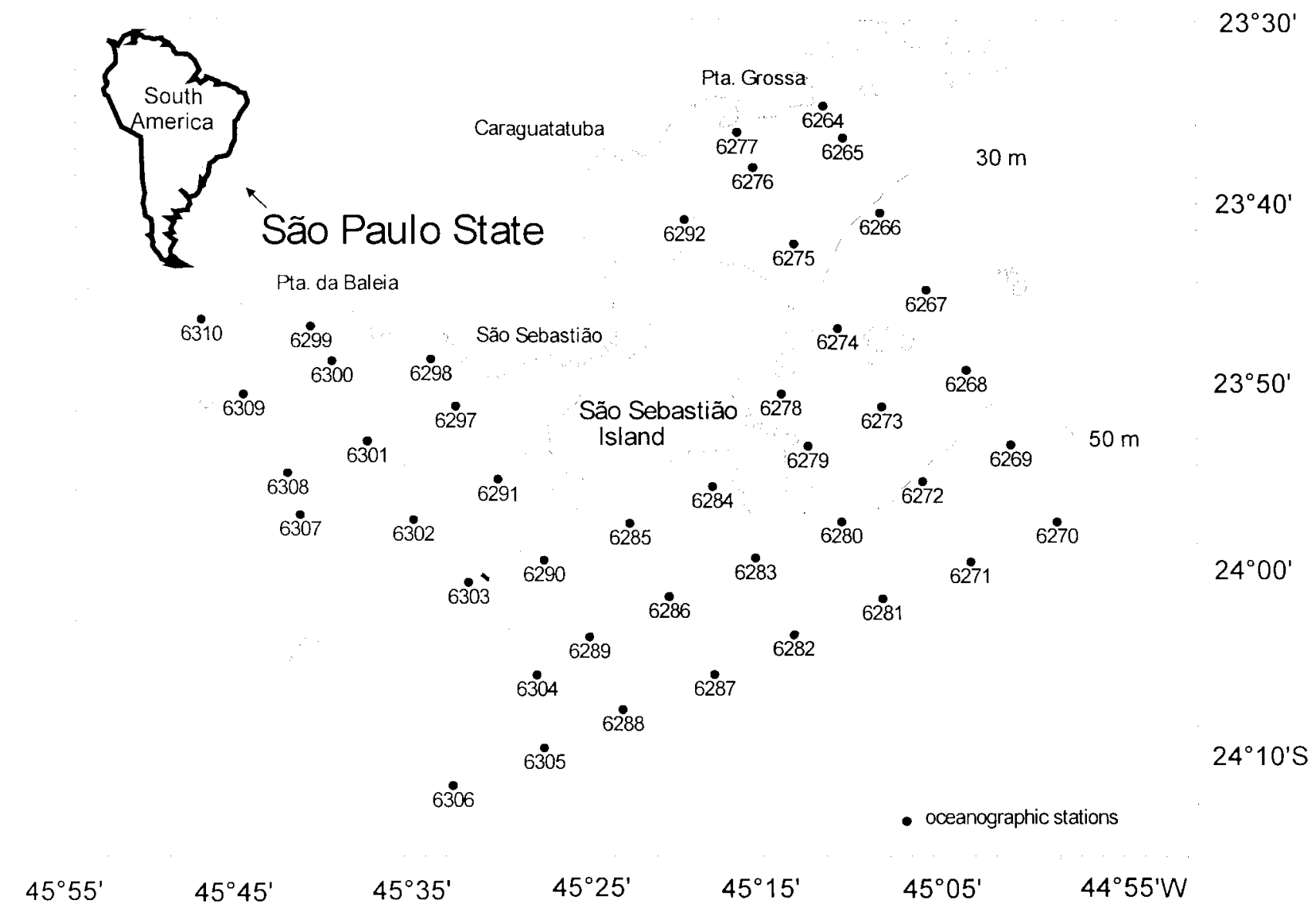

Fig. 1. Map of the study area.

Due to the transparency of the chaetognaths body and their capacity to ingest whole prey, the food items can easily be seen in the gut (Oresland, 1987). For this reason, the gut contents of 35,731 specimens of chaetognaths were analyzed through body wall without dissection. The position of the food in the gut was recorded and only the preys located at posterior region were considered, in order to eliminate data contamination by cod end feeding (Gibbons \& Stuart,1994). All food items were identified to the lowest taxonomic level possible. Well-digested food was called unidentified preys. The importance of each prey item in the diet was estimated by the percentage.

\section{Statistical analysis}

Using the Spearman Rank correlation, chaetognath abundance data was correlated with temperature and salinity data taken at several depths.
Cluster analysis was applied in order to group the species affinity, using the abundance of the species transformed in $\log (x+1)$. Euclidean distance and weighted paired-group average (WPGMA) were used for clustering. Based on the hydrographical structure of the study area, the species belonging to the nearshore marine zone extending from the coast until $20 \mathrm{~km}$ offshore was classified as neritic group, the species integrating the offshore marine zone beyond the continental shelf was named oceanic group, and the species belonging to the intermediate zone situated within the continental shelf with influence of both coastal and oceanic water mass was called semi-neritic group.

In order to compare the diet of different species, we used the Schoener index of similarity (Schoener, 1968) which measures the overlap between two categories of comparison and gives values from 0 (no overlap) to 1 (complete overlap). The overlap is biologically significant when its value exceeds 0.60 (Wallace, 1981). 
The Schoener index (D) is expressed by the following formula:

$$
D=1-0.5\left(\sum_{i=1}^{n}|P x i-P y i|\right.
$$

where:

$P x i=$ percentage of food category in the diet of species $x$

$P y i=$ percentage of food category in the diet of species $y$

$n=$ number of food categories

Because of the large numbers of welldigested food items that were not identified at species level, we considered only copepods at genus level and cladocerans and appendicularians as main categories in the similarity analysis.

\section{Results}

A complete description of temperature and salinity range in the study area can be found elsewhere in Castro Filho \& Miranda (1997). Seven species of chaetognath belonging to two genera were recorded during the survey: Sagitta friderici; $S$. tenuis, S. enflata, S. hispida, S. minima, S. bipunctata and Krohnita pacifica.

Chaetognaths were widely distributed throughout the study area, performing $0.05 \%$ (St. 6266 and St. 6267) to $2.72 \%$ (St. 6292) of the total zooplankton. Lower densities of chaetognaths $(<100$ ind. $\mathrm{m}^{-2}$ ) were found at nearshore stations and higher densities (>1000 ind $\mathrm{m}^{-2}$ ) were obtained at offshore stations.

The chaetognath species displayed a significant difference in abundance between sampling stations: S. friderici and S. tenuis were the most abundant species nearshore, occurring at densities higher than 500 ind. $\mathrm{m}^{-2}(\sim 50 \%$ of total chaetognaths). However, in offshore stations they represented less than 100 ind. $\mathrm{m}^{-2} \quad(-20 \%$ of total). On the contrary, $S$. enflata comprised up to 500 ind. $\mathrm{m}^{-2}$ in offshore $(-70 \%$ of total $)$ and less than 100 ind. $\mathrm{m}^{-2}$ ( $20 \%$ of total) in nearshore (Fig. 2).

The species $S$. hispida and $K$. pacifica showed similar distribution pattern and abundance with densities higher than 50 ind. $\mathrm{m}^{-2}(\sim 5 \%)$ in offshore and south-westward of São Sebastião Island, and lower than 8 ind. $\mathrm{m}^{-2}$ in nearshore.

$S$. minima and $S$. bipunctata were the least abundant species, densities lower than 2 ind. $\mathrm{m}^{-2}$ $(\sim 1 \%)$ being found only at few stations.

\section{Cluster analysis}

The R-mode dendrogram shows two groups of species (Fig. 3A). Group I encompassed $S$. friderici, $S$. tenuis and $S$. bipunctata, with distribution restricted mostly to nearshore region. This group includes neritic species. Group II comprised $S$. minima, K. pacifica, S. hispida and S. enflata, which were found principally in offshore region. This group contains semi-neritic species.

The stations in the Q-mode dendrogram fall into 3 groups (Fig. 3B). The first group (cluster I) was formed by the nearshore stations, composed by the highly abundant $S$. friderici/S. tenuis; the second group (cluster II) was formed by offshore stations, consisted of high number of species, including $S$. minima, $K$. pacifica, S. hispida and $S$. enflata. The third group (cluster III) encompassed also by offshore stations, located south-southwestward stations, was caracterized by dominance of $S$. enflata.

\section{Population structure}

With exception of $K$. pacifica and $S$. tentis that showed higher proportions of maturity stage II $(\sim 30 \%)$ and stages III and IV $(\sim 45 \%)$, the chaetognath species off São Sebastião were composed mainly of stages 0 and I (>40\%). Stage II averaged $30 \%$ of each species and stages III and IV performed about $10 \%$

The length was highly variable among stations, smaller individuals being found nearshore and larger individuals mainly offshore. Mean total body length of $S$. enflata, $S$. friderici, $S$. tenuis, $S$. hispida and $K$. pacifica at maturity stages II, III and IV was negatively correlated with seawater temperature at each sampling depth $(p<0.05)$. Stages 0 and I did not show significant correlation.

The biomass of each chaetognath species is shown in Table 1 . Lower values, $10 \mathrm{mg} \mathrm{DW} \mathrm{m}^{-2}$ and $500 \mathrm{mg} W W \mathrm{~m}^{-2}$, were recorded nearshore and northward of São Sebastião Island, while higher values, $1,000 \mathrm{mg} \mathrm{DW} \mathrm{m}^{-2}$ and $10,000 \mathrm{mg} \mathrm{WW} \mathrm{m}^{-2}$, were found offshore and south/south-westward of the Island (Fig. 4).

\section{Gut content}

The gut content of the 35,731 specimens analysed showed only $3,342(9.3 \%)$ containing $1-3$ preys and the remaining $32,389(90.6 \%)$ with empty guts.

The most common preys found in the gut of $S$. enflata, S. tenuis, S. friderici, S. hispida and Krohnita pacifica were small copepods of genus Oncaea, Temora, Clausocalanus as well as the cladoceran Penilia avirostris and appendicularians. The percentage of each food items is shown in Table 2. 


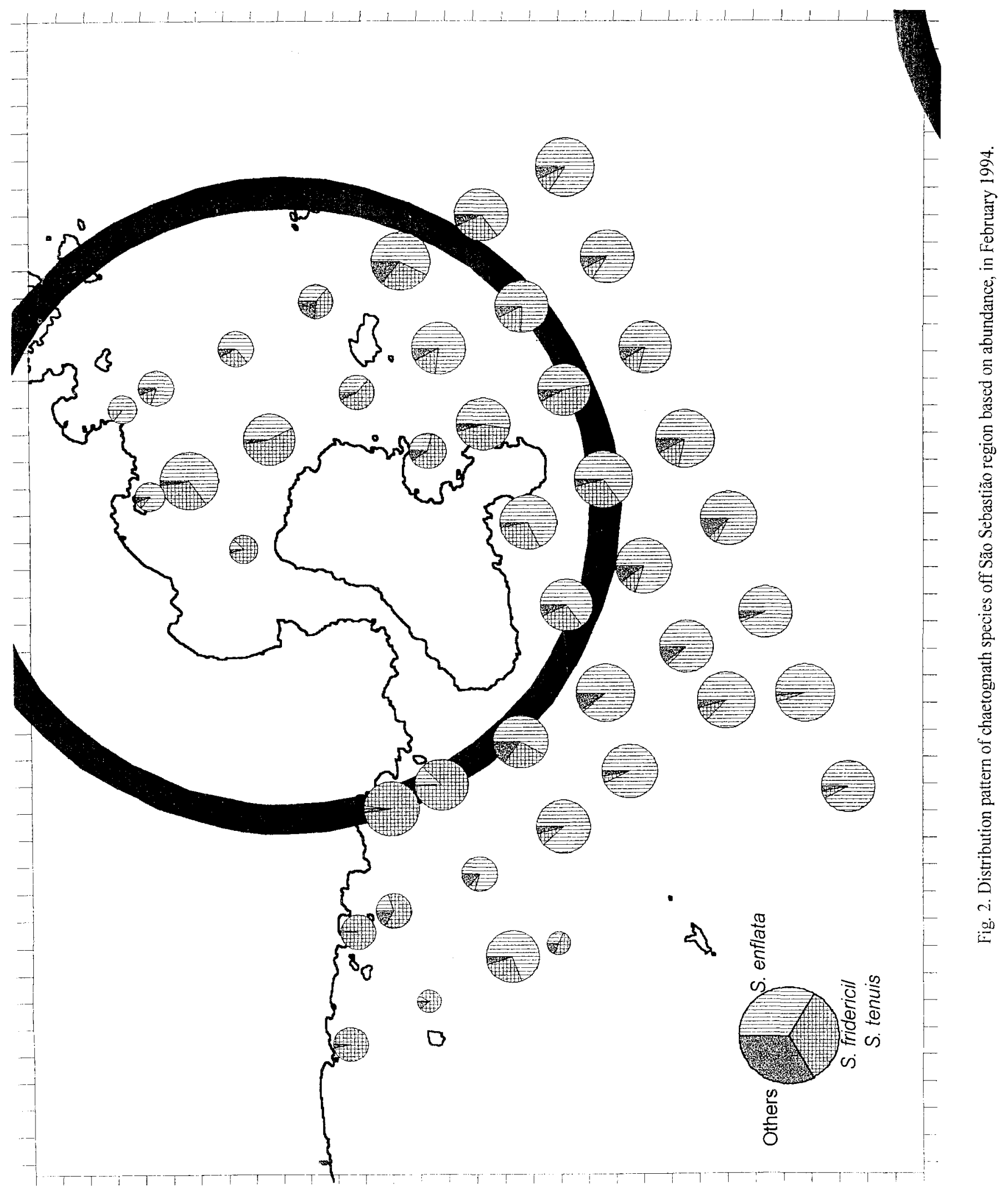



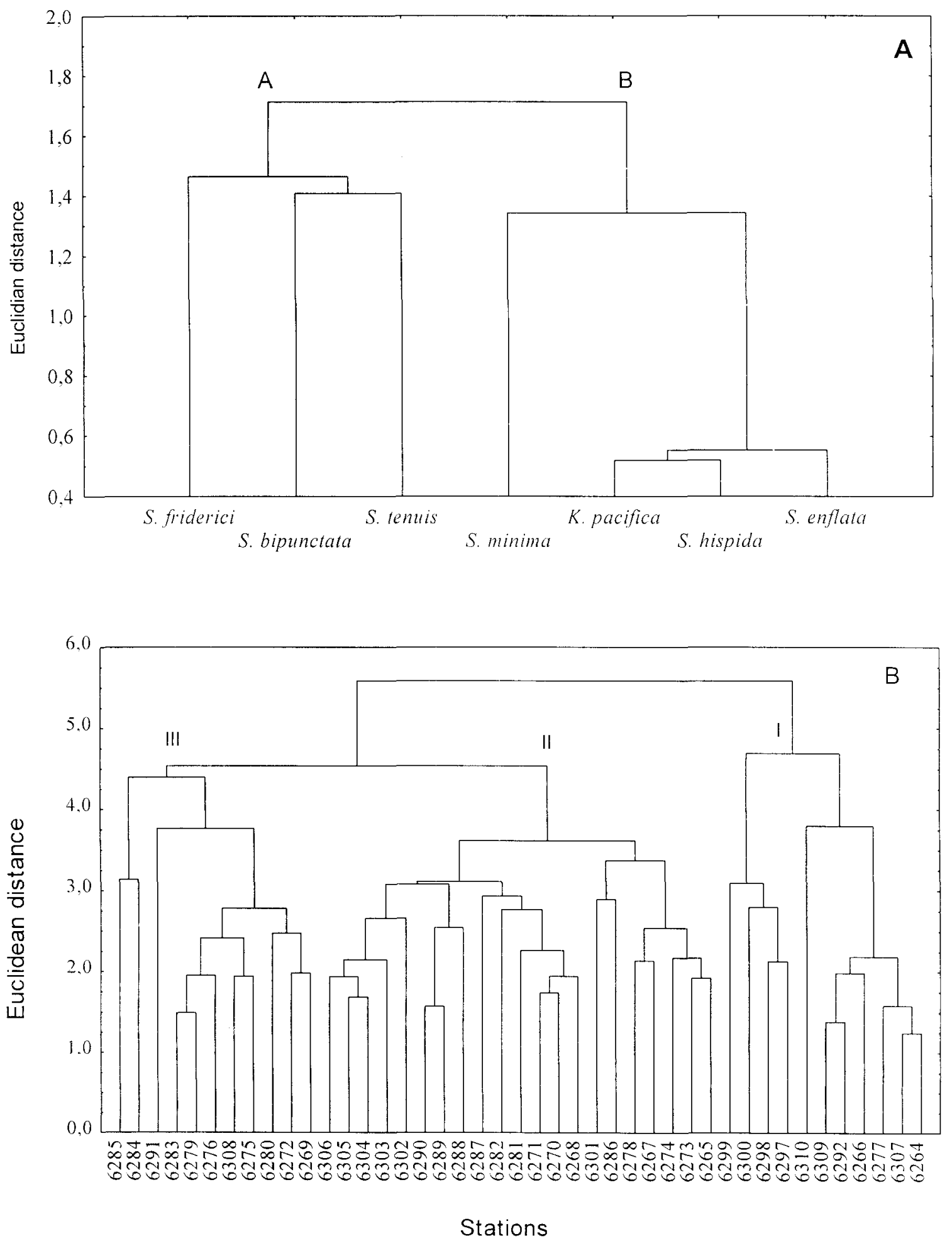

Fig. 3. Dendrograms in R-mode showing groups of chaetognath species $(A)$ and in Qmode showing groups of stations (B) off São Sebastião region, February 1994. 
Table 1. Biomass values of chaetognath species off São Sebastião region, in February, $1994(\mathrm{SE}=$ standard - error $)$.

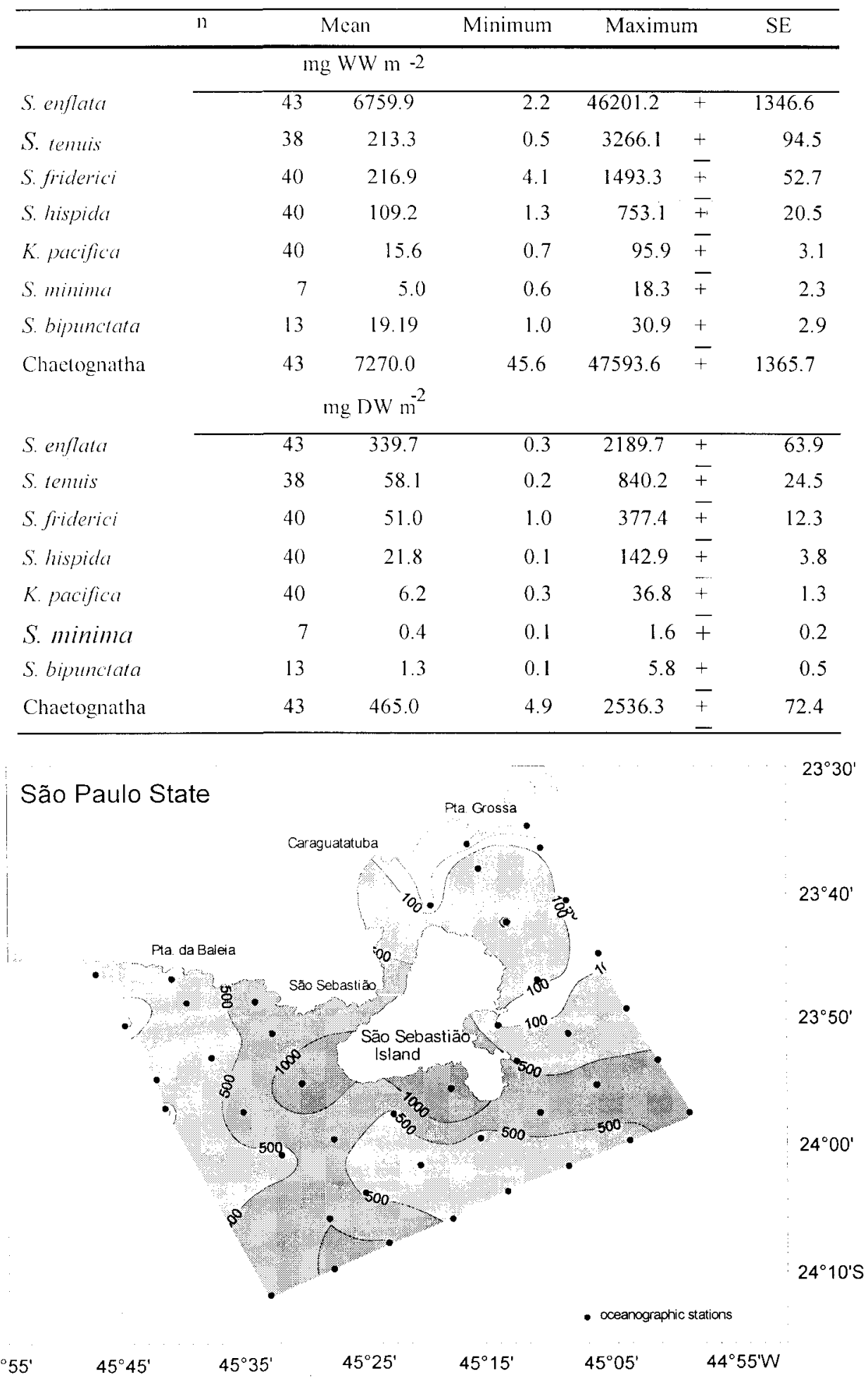

Fig. 4. Biomass (mg DW per $\mathrm{m}^{2}$ ) distribution of chaetognaths off São Sebastião region, in February 1994.

The Schoener index of similarity showed that species $S$. enflata, $S$. friderici, $S$. tenuis and $S$. hispida had quite similar diet, considering only the genus level (Table 3). 
Table 2. Percentage of food items of S. enflata. S. firderici, S. temuis, S. hispick and K. pacifica.

\begin{tabular}{|c|c|c|c|c|c|}
\hline & S. enflata & S. tenuis & S. hispida & S. friderici & K.pacifica \\
\hline \multicolumn{6}{|l|}{ Food item } \\
\hline \multicolumn{6}{|l|}{ Copepoda } \\
\hline Temora & 5,5 & 2,3 & 16,6 & 2,0 & \multirow{6}{*}{4,2} \\
\hline Clausocalanus & 3.8 & 0.9 & - & 0,5 & \\
\hline Paracalamus & 2,0 & 2,6 & 2.1 & 2,8 & \\
\hline Corycaens & 2,9 & 2.6 & 4,7 & 4,9 & \\
\hline Oncaea spp & 24,3 & 4,0 & 13,6 & 6.2 & \\
\hline Unidentilied copepod & 14,2 & 25.3 & 13.6 & 14,2 & \\
\hline \multicolumn{6}{|l|}{ Cladocera } \\
\hline Penilia avirostris & 8.8 & 8.0 & 5,1 & 8.5 & \\
\hline \multicolumn{6}{|l|}{ Apendicularia } \\
\hline Oikopleura sp & 6,2 & 17.5 & 9.4 & 20.9 & 41,7 \\
\hline Chaetognath & 1,1 & 1.4 & 2,6 & 1.0 & \\
\hline Unidentified prey & 25,0 & 29.3 & 25.5 & 28,8 & \\
\hline Others & 6,2 & 6,0 & 6,8 & 10.2 & 50,0 \\
\hline Total prey & 1902 & 348 & 235 & 885 & 24 \\
\hline
\end{tabular}

Table 3. Similarity of diel of $S$. enflata, S. friderici, $S$. tenuis and $S$. hispida calculated by Shoener index.

\begin{tabular}{lccc}
\hline & S. friderici & S. hispida & S. enflata \\
\hline S. temiis & 0.8 & 0,7 & 0.6 \\
S. friderici & - & 0,6 & 0,6 \\
S. hispida & & - & 0.8 \\
\hline
\end{tabular}

\section{Discussion}

The seven chaetognath species found in the São Sebastião region can be divided into two ecological groups: neritic and semi-neritic. The species S. friderici, $S$ temis and $S$. bipunctata formed the neritic group, whereas $S$. enflata, $S$. hispida, S. minima and $K$. pacifica belonged to semineritic group. Although the species of the latter group are also found in the epipelagic oceanic boundary, they were classified as semi-neritic because of their occurrence in the continental shelf. No oceanic group was found in the present study.

Sagitta friderici is usually associated with lower salinity and nearshore waters (McLelland, 1980) whereas $S$. temuis has been associated with higher salinity and offshore waters (McLelland, 1984). In the study area, both species showed the same distribution pattern at neritic boundaries.

Alvariño (1969) recorded a wide distribution of S. temuis extending along the neritic zones of the South-western Atlantic, from north to south, reaching the Argentinean waters. In contrast, $S$. friderici's distribution seems to be restricted. It has been registered in the northern coast of São Paulo State, where it has been associated with SACW, a colder water mass (Almeida-Prado, 1961; Liang \& VegaPérez, 1994).

In the Japanese coastal waters, Murakami (1959) recorded two different morphological types of $S$ crassa, an endemic species, the tumida type in winter and the naikaiensis type in summer. Boltovskoy (1981) considers S. friderici and S. tenuis to be one single species which may have morphological variations according to the hydrological conditions. Whether it is true or not that $S$. friderici and $S$. tenuis are the same species with morphological variations, the former could possibly have developed from the latter, becoming an endemic population of coastal zones adapted to the seasonal influence of subantartic water masses. However, we do not have enough evidence to support this hypothesis concerning the populations of $S$. tenuis and $S$. firiderici.

In this study, the occurrence of $S$. bipunctata was sporadic and its affinity with specific hydrological conditions was unclear. Pierce (1953) 
and McLelland (1984) consider it an oceanic species. Almeida-Prado (1961) and Coelho (1993) reported this species in subtropical waters, but also regarded it as typical of high salinity water as Tropical Water (TW). However, this species has not been registered in TW (Gusmão, 1986). More recently, S. bipunctata was recorded in neritic and semi-neritic regions off Ubatuba (Liang \& Vega-Pérez, 1994), as it was found in this study.

Sagitta hispida has been registered as the dominant neritic species in tropical waters of the east coast of the USA (Owre, 1960; Reeve, 1970, McLelland, 1984) and the Yucatan lagoon of Mexico (Alvarez-Cadena et al., 1996). In the subtropical waters of the South Atlantic it has been recorded as a semi-neritic species associated with $\mathrm{TW}$, characterised by temperatures between $19^{\circ} \mathrm{C}-22^{\circ} \mathrm{C}$ and high salinity (Almeida-Prado, 1961). Since TW was not detected during the study period, the data suggests that the population of $S$. hispida could be an expatriate population replaced, continually or seasonally, as a consequence of the mixing of TW with other water masses present in the region.

Regarding $K$ pacifica, the present data confirms previous findings that it is a typical species of semi-neritic waters and usually associates with $S$. hispida (Heydorn, 1959; Almeida-Prado 1968; Liang \& Vega-Pérez, 2001).

According to Grant (1991), S. minima is an oceanic species related to colder and higher salinity waters. Heydorn (1959) and Alvariño (1965) reported this species as semi-neritic and related to tropical waters. Although the presence of SACW in the São Sebastião region is a hint that $S$. minima is related to a water mass with temperature lower than $18^{\circ} \mathrm{C}$, previous studies showed that this species was more abundant in $20^{\circ} \mathrm{C}$ water observed during winter (Liang \& Vega-Pérez, 1994).

Sagitta enflata has already been wellcharacterised as a semi-neritic species of equatorial, tropical and subtropical waters (Szyper, 1978, Camiñas, 1985; Marazzo \& Nogueira, 1996), and as one of the most abundant chaetognath species of surface waters of Goa, India (Goswami, 1982). The information obtained in this study confirms the report of these authors, since $S$. enflata was also the dominant species in the São Sebastião region, accounting for $70 \%$ of the total chaetognaths at offshore stations.

Many studies on plankton have shown that the richness increases with the distance from the coastal to the oceanic zone. This is remarkably true for chaetognaths. Less than 10 chaetognath species have been registered in the coastal zones of tropical and subtropical waters (Heydorn, 1959; Fagetti, 1968, McLelland \& Heard, 1991).
A very distinct distribution pattern of $S$. friderici and $S$. enflata can be observed in this study. Almeida-Prado (1968) related their affinity with different hydrological conditions. Boltovskoy (1975) suggested that this might be due to the inter-specific competition between these species. In the São Sebastiano region, our data strongly suggests that this spatial partition seems to be related more to the hydrological conditions than an inter-specific competition, though it may exist.

The decrease in richness and abundance of chaetognath species from offshore to nearshore has been attributed to the preference of holoplanktonic chaetognath for oceanic waters (Hossfeld, 1996). In the São Sebastião region during February 1994, lower densities of chaetognaths were obtained nearshore, whereas higher densities were found offshore. The same pattern was observed concerning the biomass. These results showed that the abundance and biomass of chaetognaths increased by about two orders of magnitude toward oceanic zones, as similarly observed by Hossfeld (1996) during the rainy season at Nycoya Golf, Costa Rica. During the winter, this spatial difference might decrease by about one order of magnitude, since the differences of chaetognaths abundance and sizes regarding the distance to the coast are then lower (Liang \& Vega-Pérez, 1994).

\section{Population composition}

Regardless of the season and region, juveniles of chaetognaths are dominant in the plankton of marine environments. This was not different in the São Sebastião region, except for the species $K$. pacifica, $S$. temuis and $S$. minima which showed higher proportions of intermediate and adult stages; juveniles are very small and too slender (cross section is about $300 \mu \mathrm{m}$, Casanova, 1999) and hence passed through the mesh utilized in this study (333 $\mu \mathrm{m}$ size). Smaller mesh size net sampling should provide a better description of the population size and structure of these 3 species in São Sebastião.

Seasonal variations of the population structure have also been reported (Dunbar, 1962: Bainbrigde, 1963). The percentage of juveniles and adults in the Ubatuba region during the summer and winter was related to the hydrological conditions (Liang \& Vega-Pérez, 1994). Higher proportions of juveniles were associated with a presence of the of SACW and stratification of water column in the summer, whereas higher proportions of maturity stages II, III and IV were associated with mixing of the water column in the winter. This seasonal variation indicates possibly a more pronounced breeding period in the summer. Because of the similarity of hydrological characteristics between Ubatuba and São Sebastião we also expect a seasonal 
variation in the composition of juveniles and adults in the latter region.

\section{Feeding habits}

The diet of chaetognaths is composed of prey belonging to a wide variety of taxonomic groups, suggesting that they are opportunistic feeders. In general, the gut contents reflect the composition of the local plankton, the copepods being the most common prey registered (Rakusa-Suszczewski, 1969; Sullivan, 1980, Terazaki \& Marumo, 1982; Canino \& Grant, 1985), as was observed in this study. Copepods of the genera Oncaea, Temora, Paracalanus and Corycaeus, the dominant zooplankton of São Sebastião during February 1994, were the main preys recorded. Yet, appendicularians were significant in the diet of adults of $S$. enflata, $S$. friderici, S. hispida and $S$. tenuis. Higher percentages were registered, corresponding to their abundance in the plankton (Vega-Pérez, unpublished). According to Sziper (1978), this is likely due to the size of these preys which are slightly bigger than copepods.

However, chaetognaths are not found consuming only the dominant preys of the environment, which suggests that selective feeding might occur. Predation is related to the abundance, size, form, swimming behaviour and migration pattern of preys (Nagasawa \& Marumo, 1972; Gibbons, 1992) as well as the age and size of predators (Reeve \& Walter, 1972; Pearre, 1976). In this study, the dominance of the cladoceran $P$. avirostris and salps in the plankton at certain stations did not correspond to a higher percentage of these preys in chaetognath guts. Possibly, these preys are not suitable for chaetognaths (salps are too large to be ingested), and $P$. avirostris may too difficult to be seized.

Literature indicates, less than $30 \%$ of chaetognaths are found with 1-3-preys in their guts (Sullivan, 1980; Stuart \& Verheye, 1991; Vega-Pérez \& Liang, 1992, Liang \& Vega-Pérez, 1995). In this study, in average, less than $10 \%$ was found with food in their gut. Some factors that affect the frequency of individuals containing preys are the capture of chaetognaths at depths and times where feeding does not occur (Nagasawa \& Marumo, 1972; Oresland, 1987), evacuation of gut content due to stress provoked by sampling (Baier \& Purcell, 1997) and inhibition of ingestion due to high concentration of preys (Sullivan, 1980; Reeve, 1980).

\section{Acknowledgements}

The authors wish to thank the FAPESP, $\mathrm{CNPq}$ and CAPES for financial support and the students from Zooplankton Laboratory of Instituto Oceanográfico, Universidade de São Paulo for their kind help. We are also grateful to the valuable comments of the anonymous referees.

\section{References}

Almeida-Prado, M. S. 1961. Distribuição dos Chaetognatha no Atlântico Sul Ocidental. Bolm Inst. oceanogr., S Paulo, 11(4):15-49.

Almeida-Prado, M. S. 1968. Distribution and annual occurence of Chaetognatha off Cananéia and Santos coast (São Paulo, Brazil). Bolm Inst. oceanogr., S Paulo, 17(1):33-55.

Alvarez-Cadena, J. N.; Suárez-Morales, E. \& Mclelland, J. A. 1996. Observations on an isolated population of Sagitta hispida Conant (Chaetognatha) in a tropical lagoon system of Northeast Yucatan (Mexico). Gulf Res. Repts, 9 (3): 197-204

Alvariño, A. 1965. Chaetognaths. Oceanogr. mar. Biol. a. Rev., 3:115-194.

Alvariño, A. 1969. Los quetognatos del Atlántico: distribución y notas esenciales de sistematica. Trab. Inst. esp. Oceanogr., (37): 1-290.

Alvariño, A. 1985. Predation in the plankton realm, mainly with reference to fish larvae. Inv. Mar. CICIMAR, 2:1-122.

Baier, C. T. \& Purcell, J. E. 1997. Effects of sampling and preservation on apparent feeding by chaetognaths. Mar. Ecol. -Progr. Ser., 146(13):37-42.

Bainbridge, V. 1963. Continuous plankton records: contribution towards a plankton Atlas of the north Atlantic and the North Sea. Part VIIIChaetognatha. Bull. mar. Ecol., 6(2):40-51.

Boltovskoy, D. 1975. Some biometrical, ecological, morphological and distributional aspects of Chaetognatha. Hydrobiologia, 46(4):515-534.

Boltovskoy, D. 1981. Chaetognatha In: Boltovskoy, D. ed. Atlas del zooplancton del Atlantico Suboccidental y métodos de trabajos con el zooplancton marino. Mar del Plata, INIDEP. p. 759-791.

Camiñas, J. A. 1985. Quetognatos del Mar de Alborán (Resultados de la Campanha "Málaga 775"). Boln Inst.esp. oceanogr., 2(1):77-87. 
Canino, M. F \& Grant. G. C. 1985. The feeding and diet of Sagitla temis (Chaetognatha) in the lower Chesapeake Bay. J. Plankt. Res., 7(2):175-188.

Casanova, J.-P. 1999. Chaetognatha. In: Boltovskoy D. ed. South Atlantic zooplankton. Backhuys Leiden, Backhuys, 2:1353-1374.

Castro Filho, B. M. \& Miranda, L. B. 1997. $4^{\circ}$ Relatório sobre o projeto temático de equipe. Oceanografia da Plataforma Interna de São Sebastião (OPISS) proc. FAPESP 92/3449-0.

Cheney, J. 1985. Spatial and temporal abundance patterns of oceanic chaetognaths in the western North Atlantic I. Hydrographic and seasonal abundance patterns. Deep-Sea Res., 32(9A): 1041 1059 .

Coclho, M. J. 1993. Zooplâncton do Atlântico sudoeste $\left(27^{\circ} 59^{\prime} \mathrm{S}\right.$ a $39^{\circ} 59^{\prime} \mathrm{S}, \quad 44^{\circ} 52^{\prime} \mathrm{W}$ a $\left.56^{\circ} 56^{\prime} \mathrm{W}\right)$, com especial referencia aos Chaetognatha. M.Sc. Dissertation. Universidade de São Paulo, Instituto de Biociências. $185 \mathrm{p}$.

Dunbar, M. J. 1962. Arctic and subarctic seas and modifying effects of hydrographic difference in the environment. J. mar. Res., 20:76-91.

Fagetti, E. 1968. Quetognatos de la expedición "Marchile" I con observaciones acerca del posible valor de algunas especies como indicadoras de massas de agua fiente a Chile. Revta Biol. mar.. Valparaiso, 13(2):85-171.

Feigenbaum, D. L. \& Marris, R. C. 1984. Feeding in the Chaetognatha. Oceanogr. mar. Biol. a. Rev., 22: $343-392$.

Gibbons, M. J. 1992. Diel feeding and vertical migration of Sagitta serratodentala Krohn tasmanica Thompson (Chaetognatha) in the Southern Benguela. J. Plankt. Res., 14(2):249259.

Gibbons, M. J. \& Stuart, V. 1994. Feeding and vertical migration of the chaetognath Sagita friderici (Ritter-Zàhony, 1911) in the southern Benguela during Spring 1987, with notes on seasonal variability of feeding ecology. S. Afr. J. mar. Sci., 14:361-372.

Goswami, S. C. 1982. Occurence of swarms of Sagitta enflata (Chaetognatha) and Pleurobrachia globosa (Ctenophora) in the coastal waters of Goa Masahagar. Bull. Nat. Inst. Oceanogr., 15(3), 163166.
Grant, G. C. 1991. Chaetognatha from the central and southern Middle Atlantic Bigth. Species composition, temperature-salinity relationships, and interspecific associations. Fish. Bull. natn. mar. Fish. Sev., U.S., 89(1):33-40.

Gusmão, L. M. O. 1986. Chaetognatha planctônicos de províncias nerítica e oceânica do nordeste do Brasil (0400'00'-08 00'00' Latitude Sul). M.Sc. Dissertation. Universidade Federal de Pernambuco. 149p.

Heydorn, A. E. F. 1959. The Chaetognatha off west coast of the union South Africa. Department of Commerce and Industry, Investl Rept, Div. Sea Fish., Repub. S.Afr., 36:1-56.

Hossfeld, B. 1996. Distribution and biomass of arrow worms (Chaetognatha) in Golfo de Nicoya and Golfo Dulce, Costa Rica. Revta Biol. trop., 44(3)157-172.

Hyman, L. H. 1959. The invertebrates: smaller coelomate groups. The enteroceleous coelomates phylum Chaetognatha. New York, McGraw-Hill, $6: 1-71$.

Kimmerer, W. J. 1984. Selective predation and its impact of prey of Sagitta enflata (Chaetognatha). Mar. Ecol. Prog. Ser., 15(1-2):55-62.

Lamparelli, M. C. \& Moura, M. 1999. Mapeamento dos Ecossistemas Costeiros do Estado de São Paulo. São Paulo, CETESB. 41 p.

Liang, T. H. \& Vega-Pérez, L. A. 1994. Studies on chaetognaths off Ubatuba region. I. Distribution and abundance. Bolm Inst. oceanogr., S Paulo, $42(1 / 2): 73-48$.

Liang, T. H. \& Vega-Pérez, L. A. 1995. Studies on chaetognaths off Ubatuba region. II. Feeding habits. Bolm Inst. oceanogr., S Paulo, 43(1):3548.

Liang, T. H. \& Vega-Pérez, L. A. 2001. Diversity, abundance and biomass of epiplanktonic chaetognath off South Atlantic western sector, from Cabo Frio $\left(23^{\circ} \mathrm{S}, 42^{\circ} \mathrm{W}\right)$ to São Pedro and São Paulo Rocks $\left(01^{\circ} \mathrm{N}, 29^{\circ} \mathrm{W}\right)$. Oceanides, 16(1):34-48.

Marazzo, A. \& Nogueira, C. S. R. 1996. Composition, spatial and temporal variations of Chaetognatha in Guanabara Bay, Brazil. J. Plankt. Res., 18(12):2367-2376. 
Mclelland, J. A. 1980. Notes on the northern Gulf of Mexico occurence of Sagitta friderici RitterZàhony (Chaetognatha). Gulf Res. Repts, 6(4):343-348.

Mclelland, J. A. 1984. Observations on the chaetognath distributions in the northeastern Gulf of Mexico during the summer of 1974. NE Gulf Sci., $7(1): 49-59$.

Mclelland, J. A. 1989. An illustrated key to the Chaetognatha of the Northern Gulf of Mexico with notes on their distribution. Gulf Res. Repts, $8(2): 145-172$.

Mclelland, J. A. \& Heard, R. W. 1991. Notes on some chaetognaths from Pine cay, Turks and Caicos Islands (British West Indies). Gulf Res. Repts, 8(3):227-235.

Murakami, A. 1959. Marine biological study on the planktonic chaetognaths in the Seto Inland Sea. Bull. Naikai reg. Fish. Res. Lab., 12:1-186.

Nagasawa, S. \& Marumo, R. 1972. Feeding of a pelagic Chaetognatha Sagitta nagae in Suruga Bay, Central Japan. J. oceanogr. Soc. Japan, 28: 181-186.

Oresland, V. 1987. Feeding of the chaetognaths Sagitta elegans and S. setosa at different seasons in Gullmarsfjorden, Sweden. Mar. Ecol. -Progr. Ser., 39(1):69-79.

Owre, H. B. 1960. Plankton of Florida Curent. VI. The chaetognath. Bull. Mar. Sci., 10:255-322.

Pearre Jr., S. 1976. A seasonal study of the diet of three sympatric chaetognaths. Investigacion pesq., Santiago, 40:1-16.

Pierce, E. L. 1953. The Chaetognatha ovre the Continental Shelf of North Carolina with attention to their relation to the hydrography of the area. $J$. Mar. Res., 12(1):75-92.

Rakusa-Suszczewski, S. J. 1969. The food and feeding habits of Chaetognatha in the seas around the british Isles. Pol. Archs Hydrobiol., 16:213232.

Reeve, M. R. \& Walter, M. A. 1972. Conditions of culture food-size selection and the effects of temperature and salinity on growth rate and generation time in Sagitta hispida Conant. J. expl mar. Biol. Ecol., 9:191-200.
Reeve, M. R. 1970. The biology of Chaetognatha. I. Quantitative aspects of growth and egg production in Sagitta hispida In: Steele, J. H. ed. Marine food chains. Edinburgh, Oliver and Boyed. p. 169 189.

Reeve, M. R. 1980 Comparative experimental studies on the feeding of chaetognaths and ctenophores. J. Plankt. Res., 2:381-393.

Schoener, T. W. 1968. The Anolis lizards of Bimini: resource partioning in a complex fauna. Ecology, 49:704-726

Sullivan, B. K. 1980. In situ feeding behavior of Sagitta elegans and Eukrohnia hamata (Chaetognatha) in relation to the vertical distribution and abundance of prey at Ocean Station "P". Limnol. Oceanogr., 25(2):317-326.

Szyper, J. P. 1978. Feeding rate of the Chaetognatha Sagitla enflata in nature. Estuar. coast. mar. sci., $7(6): 567-575$.

Stuart, V. \& Verheye, H. M. 1991. Diel migration and feeding patterns of the chaetognath, Sagitta friderici, off the west coast of South Africa. J. mar. Res., 49(3):493-515.

Tanaka, S. 1973. Stock assesment by means of ichtyoplankton surveys. FAO Fish. tech. pap., 122:33-51.

Terazaki, M. \& Marumo, R. 1982. Feeding habits of meso- and bathypelagic chaetognath, Sagilla zetesios Fowler. Oceanol. Acta, 5(4):461-464

Vega-Pérez, L. A. \& Liang, T. H. 1992. Feeding of a pelagic chaetognath, Sagitta friderici Ritter Zàhony off Ubatuba region (São Paulo, Brazil). Bolm Inst. oceanogr., S Paulo, 40(1-2):93-100.

Wallace Jr, R. K. 1981. An assessment of dietoverlap indexes. Trans. Am. Fish. Soc., $110(1): 72-76$ 